\title{
Engineering Properties of Tanjung Bin Bottom Ash
}

\author{
Mohamad Hafeezi ABDULLAH ${ }^{*}$, Rasha ABUELGASIM², Ahmad Safuan A.RASHID ${ }^{3}$, Nor \\ Zurairahetty MOHDYUNUS ${ }^{4}$
}

1,3,4) Department of Geotechnics and Transportations, Faculty of Civil Engineering, Universiti

Teknologi Malaysia, 81310 Johor Bahru, Johor, Malaysia

2) Geotechnical Engineering Department, Building and Road Research Institute, University of

Khartoum, Khartoum, Sudan

\begin{abstract}
Tanjung Bin is one of the biggest coal-fired power plants in Malaysia to generate electricity. The by product from burning of the coal ash produce 42, 000 metric tons of fly ash and 8,000 metric tons of bottom ash every month. This huge amount of waste requires large area for disposal storage and also may cause environmental problems. This paper aims to study the properties of bottom ash and the possibility to be used as a substitute materials of sands. The laboratory testing program covered physical and mechanical properties of bottom ash. The physical testing includes specific gravity and particle size distribution, whereas, the mechanical properties are Standard Proctor compaction, relative density, permeability and direct shear test. The results show that the properties of bottom ash have similarities to those of sand thus there is a potential to be used as sand replacement materials in construction and engineering works.
\end{abstract}

\section{Introduction}

The demand for coal for electricity generation in Malaysia is projected to increase drastically approaching 2020. This is because coal is the cheapest and most abundant available fossil fuel in the world [1]. As show in Table 1, the total capacity of coal-fired power plant in the year 2018 is 8,795 MW accounting about $32 \%$ of the total electricity demand. Towards sustainable energy mix for Malaysia, in the long run it is expected that contribution of coal will increase up to $40 \%$.

Table 1. List of coal-fired plants in Malaysia as of 2018 [2]

\begin{tabular}{|l|c|}
\hline \multicolumn{1}{|c|}{ Plant } & Capacity (MW) \\
\hline Sultan Salahuddin Abdul Aziz Shah Power Station & 2420 \\
\hline Manjung Power Station & 2295 \\
\hline Tanjung Bin Power Station & 2100 \\
\hline Jimah Power Station & 1400 \\
\hline Mukah Power Station & 270 \\
\hline Sejingkat Power Corporation Plant & 200 \\
\hline PPLS Power Generation Plant & 110 \\
\hline
\end{tabular}


Coal ash which consists of bottom ash and fly ash is the by-product of coal combustion at coal-fired power plants, and the disposal of coal ash is always crucial to plant operators [3]. In Tanjung Bin, fly ash was sold to cement producer. However for the bottom ash, it is stored in the ash pond located in the plant complex. It is reported that, the amount of bottom ash accumulated has reached up to 1.5 million tons. In 10 years, plant operators will face issue of relocating new pond ash which will be costly. Hence, they are struggling to convince the industry players and gain authority support to utilize the potential usage of bottom ash as substitue to natural resources. Therefore, this study is carried out to investigate the properties of bottom ash and provide useful information for the industry players.

\section{MATERIALS AND SAMPLE PREPARATION}

Figure 1 shows the bottom ash samples were obtained from Tanjung Bin Power Plant, Johor. The samples were collected near the discharge point using shovel and gunny bags. During sample collection, face mask was equipt due to dust emission. Proper storage by placing the gunny bags sample in dry area and securely tied were adopted in the laboratory as advised by Tanjung Bin operators.

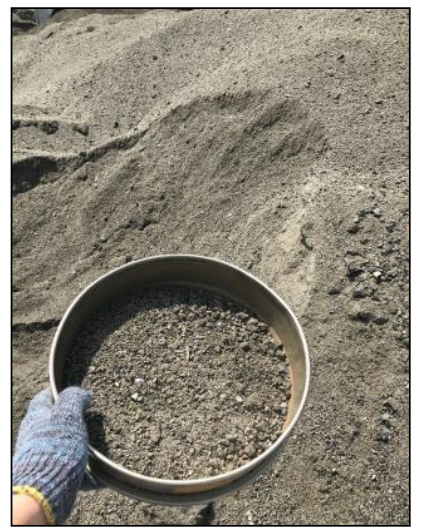

Fig. 1 Bottom ash from discharge point

The bottom ash sample collected consist of different sizes but smaller than $10.00 \mathrm{~mm}$. Before conducting any tests, the sample was oven-dried at $110^{\circ} \mathrm{C}$ from 16 to 24 hours. After drying, in order to utilize all the samples collected, the bottom ash were grinded using Los Angeles Abrasion Machine. This process breakdown the larger size of bottom ash into smaller size and passed No.10 standard sieve size $(2.00 \mathrm{~mm})$ to be used for experimental testing.

\section{RESULTS AND DISCUSSION}

In this study, physical properties test conducted on the bottom ash include specific gravity and the particle size distribution test. For mechanical characterization, the sample was subjected to Standard Proctor compaction, relative density, permeability and direct shear tests. The findings of the experimental testing were compared with other researchers and computed that the properties of bottom ash shows similarities to those of sand. 


\subsection{Grain Size Distribution}

Particle size distribution analysis was conducted on bottom ash sample. The test was carried out to determine the gradation of the particle size of the bottom ash. The particle size distribution for the samples were determined according to [4] Part 2.
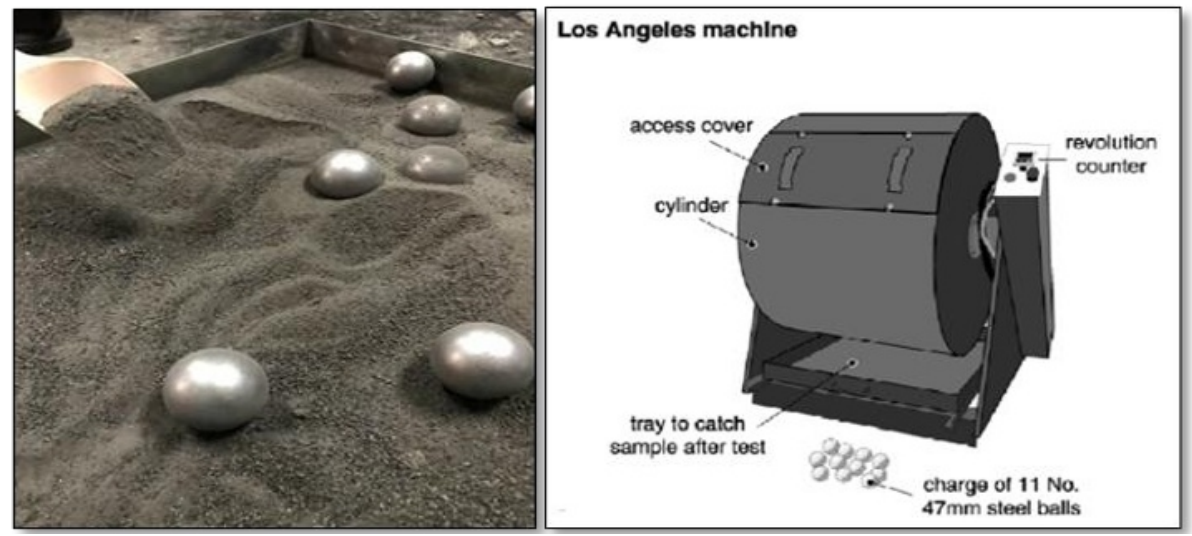

Fig. 2 Los Angeles Abrasion Testing Machine and bottom ash sample

Figure 2 shows the Los Angeles Abrasion Testing Machine used to grind the bottom ash samples to reduce the wastage. Firstly, the bottom ash samples were obtained from the Tanjung Bin power plant. Secondly, the samples was oven dry at $110^{\circ} \mathrm{C}$ from 16 to 24 hours and it let to be cooled at room temperature. Next, the revolution counter was set up at a suitable magnitude before the testing was carried out (e.g: 30-33 revolutions $/ \mathrm{min}$ ). The cylinder was cleaned up using wet sand and vacuum for any dry residue. $4 \mathrm{~kg}$ of bottom ash sample was inserted inside the cylinder chamber with 11 of steel balls into the cylinder. The access cover was fixed and the test was started at desire time interval (e.g: 15-30 minutes). Finally, the test was repeated and increase the timer for finer bottom ash sample.

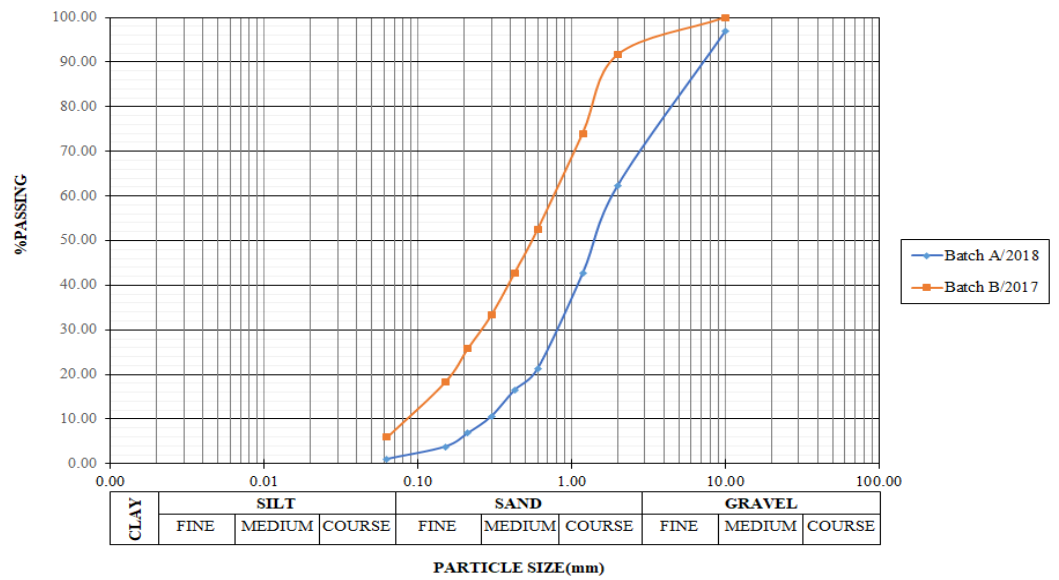

Fig. 3 Particle Size Distribution of bottom ash

Figure 3 shows the grain size distribution of bottom ash obtained from Tanjung Bin power plant. The gradation for both bottom ash before and after grind categorized as well graded size distribution. Referring to British Soil Classification System (BSCS), bottom ash sizes 
ranging from fine gravel to fine sand in which the grain sizes lies in between $10.00 \mathrm{~mm}$ and $0.063 \mathrm{~mm}$. Therefore, bottom ash obtained can be considered as coarse grained materials. In terms of average coefficient of uniformity, $\mathrm{C}_{\mathrm{u}}$ for bottom ash before grinding is 6.43 while the average coefficient of curvature, $\mathrm{C}_{\mathrm{c}}$ is 1.27 . Meanwhile, for grinded bottom ash, $\mathrm{C}_{\mathrm{u}}$ is 9.05 and $\mathrm{C}_{\mathrm{c}}$ is 1.14. According to Unified Soil Classification System (USCS), bottom ash classified as SW (well-graded sand) for both before grind and after grinding process. Hence, this have proved that the grinding process of bottom ash does not affect the gradation of the sample. Table 2 shows the values of $\mathrm{C}_{\mathrm{u}}$ and $\mathrm{C}_{\mathrm{c}}$ for Tanjung Bin bottom ash obtained by previous researchers which also agreed bottom ash exhibit the gradation of sand.

Table 2. Value of $\mathrm{C}_{\mathrm{u}}$ and $\mathrm{C}_{\mathrm{c}}$ of Bottom Ash

\begin{tabular}{|c|c|c|}
\hline Researcher & $\begin{array}{c}\text { Coefficient of uniformity, } \\
\mathbf{C}_{\mathbf{u}}\end{array}$ & $\begin{array}{c}\text { Coefficient of curvature, } \\
\mathbf{C}_{\mathbf{c}}\end{array}$ \\
\hline$[5]$ & 16.56 & 1.01 \\
\hline$[6]$ & 7.40 & 1.09 \\
\hline Before Grind & 6.43 & 1.27 \\
\hline After Grind & 9.05 & 1.14 \\
\hline
\end{tabular}

\subsection{Specific Gravity}

Small pycnometer test was used to determine the specific gravity of bottom ash and the test was performed following [4] Part 2. From the tests, the specific gravity of bottom ash was found 2.23 and 2.22 for Batch A (2018) and Batch B (2017) respectively. A lower value of the specific gravity for Tanjung Bin bottom ash was reported by [7] which is 1.9 while the higher value of 2.41 was found by [8]. [5], [9] and [10] stated that the specific gravity of Tanjung Bin bottom ash is 2.3 and 2.35 whereas [6] and [11] reported that the values of specific gravity are 2.36 and 2.38 respectivily. Table 3 sumarized the specific gravity of Tanjung bin bottom ash achieved by the past researchers.

Table 3. Summay of specific gravity tests results of bottom ash obtained from previous works

\begin{tabular}{|c|c|}
\hline Reference/ Year & Specific Gravity \\
\hline$[5] / 2010$ & 2.30 \\
\hline$[6] / 2011$ & 2.36 \\
\hline$[7] / 2012$ & 1.90 \\
\hline$[8] / 2011$ & 2.41 \\
\hline$[9] / 2014$ & 2.35 \\
\hline$[10] / 2016$ & 2.35 \\
\hline$[11] / 2016$ & 2.38 \\
\hline Batch $\mathrm{A} / 2018$ & 2.23 \\
\hline Batch B/2017 & 2.22 \\
\hline
\end{tabular}

From the values obtained from the tests results and the previous researchers mentioned above, it is clear that the bottom ash has smaller value of specific gravity compared to coarse sand and fine aggregates. According to [6], the specific gravity of the bottom ash 
related to their iron oxide contents and porosity of its particles. The amount of iron oxide contents of the bottom ash samples were depending on the source of coal ash used in burning process. Therefore, lower iron oxide contents results in lower specific gravity of bottom ash.

\subsection{Compaction}

Standard compaction test was conducted according to [4] Part 4. The compacted dry density versus the water content curve of the bottom ash are displayed in Figure 4. The results show that the optimum moisture content and maximum dry density of Tanjung Bin bottom ash are $24.5 \%$ and $1.10 \mathrm{Mg} / \mathrm{m}^{3}$. According to the previous researches tests results presented in Table 4, the typical values for maximum dry density and optimum moisture content in the range from 1.131 to $1.34 \mathrm{Mg} / \mathrm{m}^{3}$ and from 22 to $24 \%$ respectively. In term of maximum dry density, bottom ash exhibit lower value than those of the sandy soils, which in the range from $1.7-2.0 \mathrm{Mg} / \mathrm{m}^{3}$.

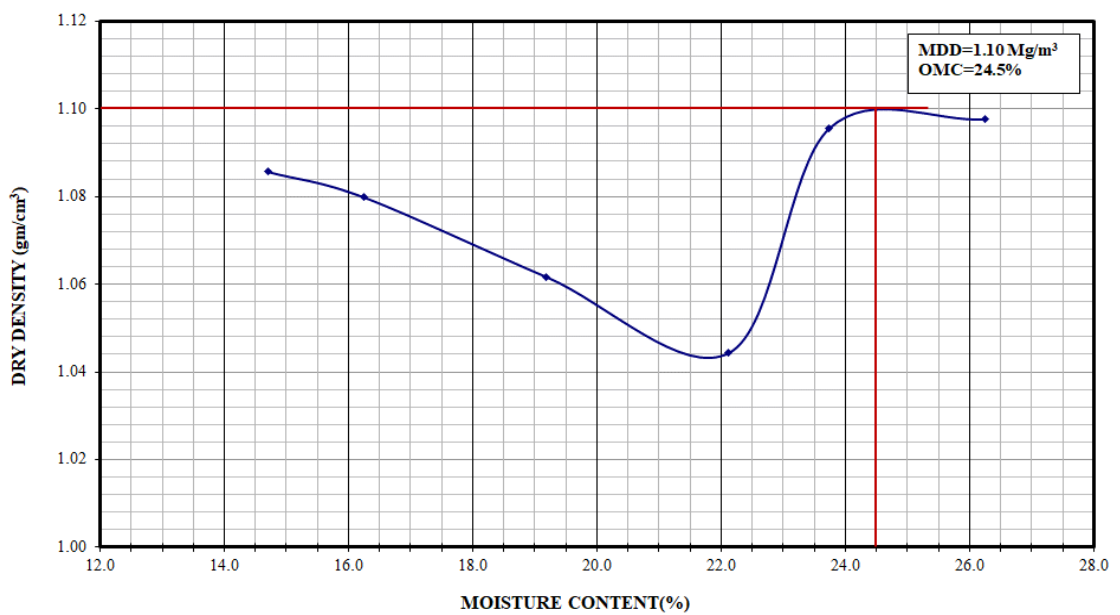

Fig. 4. Compaction curves of Tanjung Bin bottom ash

Table 4. Summay of standard proctor compaction tests results of bottom ash obtained from presvious studies

\begin{tabular}{|c|c|c|}
\hline Reference / Year & $\begin{array}{c}\text { Maximum dry density } \\
\left(\mathbf{M g} / \mathbf{m}^{\mathbf{3}} \mathbf{)}\right.\end{array}$ & $\begin{array}{c}\text { Optimum moisture } \\
\text { content } \mathbf{( \% )}\end{array}$ \\
\hline$[5] / 2010$ & 1.310 & 21.5 \\
\hline$[6] / 2011$ & 1.140 & 24.0 \\
\hline$[8] / 2011$ & 1.32 & 24.09 \\
\hline$[9] / 2014$ & 1.338 & 22.5 \\
\hline$[10] / 2016$ & 1.338 & 23.0 \\
\hline$[11] / 2016$ & 1.131 & 23.0 \\
\hline$[12] / 2013$ & 1.339 & 22.0 \\
\hline$[13] / 2012$ & 1.140 & 24.0 \\
\hline Batch A/2018 & 1.100 & 24.5 \\
\hline
\end{tabular}




\subsection{Permeability}

The permeability of Tanjung Bin bottom ash was measured by a constant head permeability test as it contains coarse materials referring to [4] Part 5. Two different batch of bottom ash were obtained, Batch A in 2018 while Batch B in 2017. Figure 5 shows the test conducted for the bottom ash sample. The coefficient of permeability calculated were $6.09 \times 10-3 \mathrm{~m} / \mathrm{s}$ for Batch A and $2.41 \times 10-3 \mathrm{~m} / \mathrm{s}$ for Batch B. Table 5 summarized the values of coefficient of permeability obtained from other researchers and their sources.

Table 5. Permeability of bottom ash, $k$

\begin{tabular}{|c|c|c|}
\hline Source & $\begin{array}{c}\text { Coefficient of } \\
\text { Permeability, } \mathbf{k} \\
(\mathbf{m} / \mathbf{s})\end{array}$ & Reference / Year \\
\hline Malaysia (Tanjung Bin) & $6.09 \times 10-3$ & Batch A/2018 \\
\hline Malaysia (Tanjung Bin) & $2.41 \times 10-3$ & Batch B/2017 \\
\hline Malaysia (Tanjung Bin) & $1.72 \times 10-4$ & {$[5] / 2010$} \\
\hline Malaysia (Tanjung Bin) & $1.80 \times 10-4$ & {$[11] / 2016$} \\
\hline Malaysia (Tanjung Bin) & $1.59 \times 10-3$ & {$[14] / 2016$} \\
\hline Lithuania (Klaipeda Plant) & $7.39 \times 10-5$ & {$[15] / 2018$} \\
\hline Nigeria (Kano Municipal) & $6.23 \times 10-4$ & {$[16] / 2012$} \\
\hline
\end{tabular}

As shown in Table 5, other researchers obtained the coefficient of permeability of bottom ash lies in range of 10-3 to $10^{-5} \mathrm{~m} / \mathrm{s}$. According to [17],coefficient of permeability of soils ranging from 10-2 to $10^{-5} \mathrm{~m} / \mathrm{s}$ categorized as good drainage materials and comprise of clean sands, clean sand and gravel mixtures. Therefore, bottom ash falls into these categories and suitable as a drainage materials.

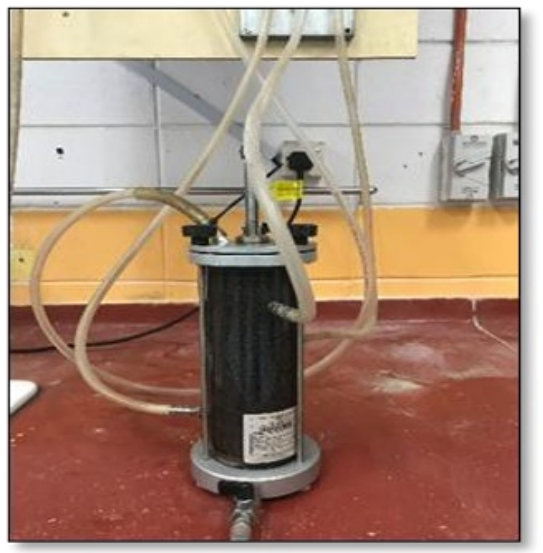

Fig.5 Permeameter Cell with bottom ash

\subsection{Relative Density}

The relative density of bottom ash was determined using [18] and [19]. The test was carried out to appropriately define the looseness and denseness of the bottom ash sample. 
The relative density can be expressed in terms of maximum and minimum indexes and dry densities based on Equation 1.

$$
D_{d}=\frac{\rho_{d \max }\left(\rho_{d}-\rho_{d \min }\right)}{\rho_{d}\left(\rho_{d \max }-\rho_{d \min }\right)} \times 100
$$

Where $\rho_{\mathrm{dmax}}$ is the reference dry density of a soil in the densest state of compactness that can be attained using a standard laboratory compaction procedure; $\rho d m i n$ is the reference dry density of a soil in a standard state of compactness; and $\rho d$ is the dry density of a soil at the given void ratio. According to [20], relative density test is applicable only to soils that contains less than $15 \%$ of silt or clay and provided that it is free draining and cohesionless. For Tanjung Bin bottom ash samples, it was recorded that the silt or clay contents ranging from $1-6 \%$. Hence, the test is applicable in obtaining the relative density of the bottom ash.

Table 6. Minimum and maximum index density of bottom ash

\begin{tabular}{|c|c|c|}
\hline $\begin{array}{c}\text { Minimum index } \\
\text { density, } \boldsymbol{\rho}_{\text {dmin }}\left(\mathbf{g} / \mathbf{c m}^{\mathbf{3}}\right)\end{array}$ & $\begin{array}{c}\text { Maximum index } \\
\text { density, } \boldsymbol{\rho}_{\text {dmax }}\left(\mathbf{g} / \mathbf{c m}^{\mathbf{3}}\right)\end{array}$ & Reference / Year \\
\hline 0.886 & 1.056 & Batch A/2018 \\
\hline 0.896 & 1.120 & Batch B/2017 \\
\hline 0.726 & 1.168 & {$[11] / 2016$} \\
\hline
\end{tabular}

\subsection{Direct shear}

Direct shear tests was performed on the Tanjung Bin bottom ash based on [4] Part 7. The results show that the apparent cohesion and angle of internal friction are $11.81 \mathrm{kPa}$ and $30.57^{\circ}$ respectiviley. The cohesion value obtained from the test is slightly higher than reported by [5], [8], [9] and [20] which are 3.8, 1.36, 6.60 and $7.28 \mathrm{kPa}$. However the value is quiet similar to that stated by [13]. Table 7 shows the summarrized of direct shear test results for Tanjung Bin bottom ash from past studies. For angle of internal friction, the value obtained from the test is quite low compared to [9], [13] and [21], whereas it is closer to the values reported by [9] and [8]. According to [22] the values of angle of internal friction of sand range from $27^{\circ}$ to $37^{\circ}$ while the higher values are ranging between $32^{\circ}$ to $37^{\circ}$. Based on the direct shear tests reults for Tanjung Bin bottom ash which are stated in Table 7; the angle of internal friction for bottom ash falls within the range of sand soil.

Table 7. Summary of Direct shear tests results for Tanjung Bin bottom ash obtained from previous researches

\begin{tabular}{|c|c|c|}
\hline Reference / Year & $\mathbf{c ~ ( k P a )}$ & $\boldsymbol{\phi}$ (degree) \\
\hline$[5] / 2010$ & 3.80 & 32.00 \\
\hline$[8] / 2011$ & 1.36 & 33.73 \\
\hline$[9] / 2014$ & 6.60 & 37.85 \\
\hline$[13] / 2012$ & 9.89 & 35.98 \\
\hline$[21] / 2015$ & 7.28 & 38.83 \\
\hline Batch $\mathrm{A} / 2018$ & 11.81 & 30.57 \\
\hline
\end{tabular}




\section{Conclusion}

This paper has studied the physical properties of bottom ash obtained from Tanjung Bin Power Plant Station and compared them with those available in the literature. Based on the laboratory test that had been conducted in determining the engineering properties bottom ash as well as the results obtained from the previous research, it can be concluded that, the engineering properties of bottom ash are quiet similar to those of sand, therefore the bottom ash has great potential for using in geotechnical applications. This can be significantly solve the problem of the disposal of bottom ash and also helps in reducing the cost of construction projects.

\section{Acknowledgement}

The authors would like to thank the Management of Tanjung Bin Power Plant, Pontian Johor for supplying the bottom ash samples and showed their interest on the outcome of the research works. The authors also would like to acknowledge the Ministry of Higher Education of Malaysia (MOHE) for financial support through Research University Grant Consolidation Behavior of Soft Ground Treated with a Group of Bottom Ash Columns Vote No. Q.J130000.2522.19H75 and Universiti Teknologi Malaysia (UTM) for providing the laboratory testing facilities.

\section{References}

1. A. Jamaludin, "Energy mix and alternatives energy for sustainable development in Malaysia," Tokyo, Japan: 9th International Students Summit on Food, Agriculture and Environment in the New Century, (2009).

2. "List of coal-fired plants in Malaysia," Retrieved from List of Power Stations in Malaysia website :https://en.wikipedia.org (2018).

3. "Malakoff Corporation Berhad Annual Report 2017 " in "Energising Growth," (2017).

4. B. Standard, "1377:1990," Methods of test for soils for civil engineering purposes, (1990).

5. A. Marto, K. A. Kassim, A. M. Makhtar, L. F. Wei, and Y. S. Lim, "Engineering characteristics of Tanjung Bin coal ash," Electronic Journal of Geotechnical Engineering, vol. 15, pp. 1117-1129, (2010).

6. A. R. Awang, A. Marto, and A. M. Makhtar, "Geotechnical properties of Tanjung Bin coal ash mixtures for backfill materials in embankment construction," Ejge, vol. 16, pp. 1515-1531, (2011).

7. A. U. Abubakar and K. S. Baharudin, "Properties of concrete using tanjung bin power plant coal bottom ash and fly ash," International Journal of Sustainable Construction Engineering and Technology, vol. 3, no. 2, pp. 56-69, (2012).

8. M. B. Hasan, A. Marto, M. Hyodo, and A. Makhtar, "The strength of soft clay reinforced with singular and group bottom ash columns," Electronic Journal of Geotechnical Engineering, vol. 16, (2011).

9. A. Marto, M. Hasan, M. Hyodo, and A. M. Makhtar, "Shear strength parameters and consolidation of clay reinforced with single and group bottom ash columns," Arabian Journal for Science and Engineering, vol. 39, no. 4, pp. 2641-2654, (2014).

10. A. Marto, N. A. Rosly, C. S. Tan, F. Kasim, N. Z. M. Yunus, and R. Moradi, "Bearing Capacity Of Soft Clay Installed With Singular And Group Of Encased Bottom Ash Columns," Jurnal Teknologi, vol. 78, no. 7-3, pp. 105-110, (2016). 
11. R. Moradi, Physical and Numerical Modelling of Bottom Ash Columns Installed Soft Clay, PhD Thesis, Universiti Teknologi Malaysia, Johor Bahru (2016).

12. A. Marto, M. A. Hassan, A. M. Makhtar, and B. A. Othman, "Shear strength improvement of soft clay mixed with Tanjung Bin coal ash," APCBEE procedia, vol. 5, pp. 116-122, (2013).

13. A. R. Awang, A. Marto, and A. M. Makhtar, "Morphological and strength properties of Tanjung Bin coal ash mixtures for applied in geotechnical engineering work," International Journal on Advanced Science, Engineering and Information Technology, vol. 2, no. 2, pp. 168-175, (2012).

14. M. Hasan, N. Pangee, M. Nor, and S. Suki, "Shear Strength of Soft Clay Reinforced With Single Encased Bottom Ash Columns," ARPN Journal of Engineering and Applied Sciences, vol. 11, no. 13, (2016).

15. A. Vaitkus, J. Gražulytė, V. Vorobjovas, O. Šernas, and R. Kleizienė, "Potential of mswi bottom ash to be used as aggregate in road building materials," Baltic Journal of Road and Bridge Engineering, Article vol. 13, no. 1, pp. 77-86, (2018).

16. H. M. Alhassan and A. M. Tanko, "Characterization of solid waste incinerator bottom ash and the potential for its use," International Journal of Engineering Research and Applications (IJERA), vol. 2, no. 4, pp. 516-522, (2012).

17. K. Terzaghi, R. B. Peck, and G. Mesri, Soil mechanics in engineering practice. John Wiley \& Sons, (1996).

18. ASTM D4253-00: Standard test methods for maximum index density and unit weight of soils using a vibratory table (reapproved 2006). ASTM International, West Conshohocken, PA, USA, p. 15, (2006a).

19. ASTM D4254-00: Standard test methods for minimum index density and unit weight of soils and calculation of relative density (reapproved 2006). ASTM International, West Conshohocken, PA, USA, p. 9, (2006b).

20. B. Hamidi, S. Varaksin, and H. Nikraz, "Relative density concept is not a reliable criterion," Proceedings of the Institution of Civil Engineers - Ground Improvement, vol. 166, no. 2, pp. 78-85, (2013).

21. S. Suki, A Study Of The Undrained Shear Strength Of Soft Clay Reinforced With 10mm And 16mm Diameter Single Encapsulated Bottom Ash Column, Degree Thesis, Universiti Malaysia Pahang, (2015).

22. Budhu, Muni. Soil mechanics fundamentals, John Wiley \& Sons, (2015). 